KAROLINA KOSTYRA

Instytut Nauk o Kulturze

Uniwersytet Śląski w Katowicach
Images

vol. XXVII/no. 36

Poznań 2020

ISSN 1731-45Ox

\title{
Szafa marzeń. \\ Dziecięce kryjówki w E.T. Stevena Spielberga
}

\begin{abstract}
Aвstract. Kostyra Karolina, Szafa marzeń. Dziecięce kryjówki w E.T. Stevena Spielberga [The Dream Closet. Children's hiding places in Steven Spielberg's E.T. the Extra-Terrestrial]. "Images" vol. XXVII, no. 36. Poznań 2020. Adam Mickiewicz University Press. Pp. 41-55. ISSN 1731-450X. DOI 10.14746/i.2020.36.03.

The article contains an analysis of domestic space in E.T., adopting the perspective of the "child's gaze". The filmmakers made efforts to present reality from a child's viewpoint. Among the strategies applied for this purpose, we find a detailed approach to grasping the atmosphere of children's bedrooms. The wardrobe, intimate lighting, cozy nooks and child's props allow the creation of a space of autonomy and the uncanny effect, which slips away from adults' perception. The author uses works on the anthropology of place, the psychoanalysis of dreams, film studies analyses of E.T. and also the history of cinematic representation of children's worlds in order to describe the specificity of domestic space in Spielberg's movie. At the same time, the author proposes that E.T. can be interpreted as a movie about the relative independence of children's worlds in relation to the overpowering and stifling American suburbs. If we follow the proposed interpretation, then the popular judgment of E.T. as a conservative and family narration from Reagan's days would seem to be too one-sided.
\end{abstract}

KeYwoRDs: E.T. the Extra-Terrestrial, Steven Spielberg, children's bedroom, American cinema, child's gaze, mise en scène, film lighting

Domy budowane zgodnie z potrzebami dzieci składałyby się wyłącznie ze strychów i okapów, wielkich szaf i maleńkich drzwiczek, regałów i wnęk i mrocznych, zacienionych miejsc oraz zsypów na pranie, wind kuchennych, przestrzeni tajemnicy i eksploracji.

S. Bartlett, L. Chawla

Omawiając film E.T. (1982), analitycy, recenzenci i biografowie Stevena Spielberga często powołują się na metafory związane $\mathrm{z}$ bezpieczną przestrzenią. Ciepłe, „domowe” skojarzenia rodzą się u badaczy mierzących się z fenomenem filmu prezentującego wizję kosmosu, „W którym każda istota ma swoje przytulne i bezpieczne miejsce"[1]. Zważywszy na to, że sam reżyser wielokrotnie podkreślał, iż opowieść o chłopcu i kosmicie jest jego najbardziej osobistym filmem, dzieło i jego twórca opisywani są poprzez paralele, wedle których wraz z E.T., „kryjącym się w garderobianej szafie, Spielberg sam wyszedł ze swojej emocjonalnej szafy" [2]. Również reżyser uciekał się do cokolwiek osob-

[1] H. Ruppersberg, The Alien Messiah, [w:] Alien Zone: Cultural theory and contemporary science fiction cinema, red. A. Kuhn, London, New York 1990, s. 36.
[2] G. Reiter, Fathers and Sons in Cinema, Jefferson, London 2008, s. 112. 
liwych sformułowań związanych z bezpiecznymi wnętrzami. Pracę na planie pośród kobiet i dzieci porównał do matczynego łona: „tworzenie tego filmu odbywało się jakby w łonie. Bardzo, bardzo ciepłym łonie” [3]. W innych, bardziej konwencjonalnych skojarzeniach łączących się z nastrojowością E.T. twórca przywoływał ukojenie, jakie dawało mu w dzieciństwie „zasypianie w swoim leżaku ze szklanką lemoniady w dłoni”[4].

Metaforyka domu i jego wyposażenia współgra z tematem historii - powrotem do domu i aklimatyzacją w przestrzeni rozpościerającej się poza nim. Na płaszczyźnie tych archetypalnych, również dla filmowej popkultury, motywów twórcy E.T. wprowadzili do kina amerykańskiego novum - domem były już nie tylko użytkowane głównie przez dorosłych wnętrza (takie jak salon i kuchnia), lecz także - a może nawet przede wszystkim - przestrzenie zamieszkiwane przez dzieci. Choć konstrukcja pokoju filmowego Elliotta jest odwzorowaniem dawnej sypialni Spielberga [5], to rdzeń filmu sięga nie tylko poza jednostkowe doświadczenie twórcy, ale również poza krąg wrażeń dziecka wychowanego na amerykańskich przedmieściach. Domowa przestrzeń w E.T. jest bowiem wyrazem wspólnej wszystkim dzieciom potrzeby odnalezienia przytulnego, ale i stymulującego wyobraźnię kąta - bezpiecznej bazy zbudowanej z koca i krzeseł, sekretnego pomieszczenia na strychu, szafy, w której można ukryć się przed dorosłymi.

Widzowie E.T. pamiętają z pewnością, że akcja filmu nie rozgrywa się wyłącznie $\mathrm{w}$ domu, ale również $\mathrm{w}$ lesie, na podmiejskich drogach i w innych otwartych przestrzeniach. Najbardziej ikoniczne kadry przedstawiają przecież rowerową przejażdżkę po niebie podczas pełni Księżyca. O wadze tego motywu świadczy również to, że lot zostaje zdublowany w trakcie finałowego pościgu. Obydwie sceny wprowadzają do filmowego świata oddech otwartych przestrzeni. Las i polana pełnią natomiast funkcję baśniowego otoczenia, w którym po raz pierwszy i ostatni widzimy tytułowego kosmitę. Co jednak istotne, to nie plenery, lecz domowe pomieszczenia będą głównym tłem historii i podstawowym źródłem tonacji filmu. Nastrojowość E.T. realizuje się w zacienionych wnętrzach sypialni dziecięcej i ciepłym świetle szafy wyłożonej pluszowymi maskotkami.

Wejście do pokoju

W obrębie domowej przestrzeni utarte zwyczaje, jakie są udziałem szczęśliwych dzieci (kąpiel, zabawa, czytanie bajek na dobranoc), nabierają cech magicznych, a iście fantastyczne zdarzenia wtapiają się w codzienność. W zaczarowywaniu codzienności i urealistycznieniu magii pomógł twórcom wybór odpowiedniego domu - budynku znajdującego się na szczycie wysokiego podjazdu, w bezpośredniej bliskości gór[6]. Podmiejski dom, w którym zatrzymał się przybysz, miał być

[3] F. Sanello, Spielberg: The Man, the Movies, the Mythology, Lanham, New York, Oxford 2002, s. 109. [4] J. Hoberman, Make My Day: Movie culture in the age of Reagan, New York, London 2019, s. 177.
[5] Zob. P.M. Taylor, Steven Spielberg: The man, his movies, and their meaning, London, Basford 1999, s. 56.

[6] Zob. J.C. Tibbetts, Those Who Made It: Speaking with the legends of Hollywood, New York 2015, s. 106. 
„trochę jak portal”[7]. Scenograf filmu Jim Bissell chciał, żeby było to lokum na styku zwyczajnego i niezwykłego miejsca, takiego, które jest odpowiednim tłem dla rutynowych dziecięcych czynności, ale ma też w sobie coś magicznego [8]. Góry malujące się na dalszym planie ujęć plenerowych nadały okolicy romantycznego charakteru. Szczególnie istotne było jednak stworzenie czarodziejskiej atmosfery we wnętrzach[9].

Od momentu, gdy ścieżka usypana z czekoladowych draży zaprowadziła E.T. do dziecięcego pokoju, to miejsce stało się także jego własną przestrzenią. $\mathrm{Na}$ drzwiach sypialni chłopca znajduje się napis „WEJŚCIE”. Widoczna w kilku ujęciach tabliczka informuje nas, że właśnie za progiem tego pomieszczenia rozpocznie się coś wielkiego. Pierwszym ruchem Elliotta jest przykrycie przybysza kocem i zamknięcie drzwi sypialni. Sekretny charakter przedsięwzięcia podkreśli doklejony na drzwiach już w późniejszych scenach świstek $\mathrm{z}$ napisem „WZBRONIONE”. Dorosłym wstęp wzbroniony - ta przestrzeń należy wyłącznie do dzieci. John W. Wright pisze, że to właśnie intymna sfera sypialni dziecięcej pozwala zacieśnić więzy między tytułowym bohaterem a trójką rodzeństwa[10].

Pokój Elliotta jest nieuporządkowany, ale przez to bardziej swojski. Na ścianach wiszą wizerunki superbohaterów, tarcze do gry w rzutki i plakat Elvisa Costello. Biurko i szafki zastawione są zabawkami, pomocami naukowymi i sprzętami elektronicznymi. Pomieszczenie urządzono, jak mówił reżyser, w guście chłopca z przedmieść[11]. Znajdują się tam między innymi zabawki będące intertekstualnymi odniesieniami do dwóch pierwszych części Gwiezdnych wojen (1977, reż. G. Lucas; 1980, reż. I. Kershner). Taki styl scenograficzny, w którym faworyzowane są sypialnie bogate w popkulturowe rekwizyty, będzie charakterystyczny dla kolejnych produkcji wytwórni Amblin Entertainment, między innymi Gremliny rozrabiają (1984, reż. J. Dante) i Goonies (1985, reż. R. Donner), a także filmów imitujących Spielbergowskie rozwiązania, czego przykład stanowią Łowcy potworów (1987, reż. F. Dekker) i Making Contact (1985, reż. R. Emmerich). Angus McFadzean określa tego rodzaju realizacje mianem „kina fantastyki przedmieść”, którego jeden z wyróżników stanowi właśnie charakterystycznie urządzona sypialnia dziecięca - chłopięcy pokój „W stylu amerykańskim”, pełen zabawek oraz filmowych i naukowych plakatów[12]. Po premierze E.T. podobne przestrzenie widoczne będą $\mathrm{w}$ amerykańskich filmach $\mathrm{z}$ dziecięcym bohaterem - czasem jako tło, innym razem w roli pełnoprawnego bo-

[7] F. Hannigan, Filmcraft: Production design, London 2013, s. 24

[8] Zob. ibidem.

[9] Zob. A.D. Lowell, Production design for E.T., „American Cinematographer” 1983, vol. 64, no. 1, S. 51.

[10] Zob. J.W. Wright, Levinasian ethics of alterity: The face of the other in Spielberg's cinematic language, [w:] Steven Spielberg and Philosophy: We're gonna need a bigger book, red. D.A. Kowalski, Lexington 2008, s. 58.

[11] Zob. G.E. Turner, Steven Spielberg and E.T. the extra-terrestrial, „American Cinematographer” 1983, vol. 64 , no. 1 , s. 8 o.

[12] Zob. A. McFadzead, Suburban Fantastic Cinema: Growing up in the late twentieth century, London, New York 2019, s. 44, 84, 112. 
hatera. Jednakże na tle innych produkcji „fantastyki przedmieść” dzieło Spielberga wyjątkowo czule portretuje sypialnię dziecięcą. Według Fredericka Wassera w tym filmie „kamera większym szacunkiem obdarza zabawki i inne istotne dla dzieci przedmioty niż rzeczy dorosłych"[13].

Dla chłopięcego bohatera ważny jest każdy element tego zacisznego królestwa. Kiedy zaprasza do środka nowego kolegę, od razu zapoznaje go $\mathrm{z}$ ważnymi przedmiotami: figurki z filmów, cukierki Pez, akwarium, jedzenie dla rybki, plastikowy rekin, orzeszek-skarbonka, resorak... W dziecięcej hierarchii przedmiotów drobiazgi zajmują wysokie miejsce[14]. W myśli Waltera Benjamina taki stosunek do rzeczy wiąże się z praktykowaniem kolekcjonerstwa pozwalającego tworzyć samodzielnie małe światy - pomysłowe struktury, odmienne od kompozycji dorosłych[15]. Specyficzne zbieractwo, jakiego podejmują się niedorośli, ujawnione jest we fragmencie filmu ukazującym Gertie ciągnącą do pokoju Elliotta wózeczek z lalką i przywiędłym kwiatem. Najbardziej twórczym kolekcjonerem jest jednak tytułowy bohater, który z parasola, widelca, puszki po kawie i elektronicznej zabawki konstruuje kosmiczny „telefon”. W pokoju dziecięcym opatrzone rzeczy i znajome miejsca nabierają nowych znaczeń. Widać to między innymi w scenie ukazującej lewitujące owoce, które poprzez swój ruch symulują obroty planet. Pokój Elliotta nabiera wtedy kosmicznego wymiaru dzięki magicznym sztuczkom budzi się w nim nowe życie[16].

\section{Intymne oświetlenie}

W E.T. poszczególne części domu miały tchnąć inną nastrojowością. Pomieszczenia, w których przebywa matka trójki rodzeństwa, to "pokoje dorosłych”, jak określa je scenograf: raczej zimne, eleganckie i nieatrakcyjne dla dziecka[17]. Wnętrza zamieszkiwane przez Elliotta i Gertie są ich przeciwieństwem - wypełniają je ciepłe dywany i ciepłe światło. Bissel podkreśla, że: „pokoje dziecięce były zaprojektowane jako miejsce reprezentujące ucieczkę od okrutnej, szarej rzeczywistości. Moim najważniejszym celem było stworzenie domu, który będzie małym, uroczym gniazdkiem" [18]. Szczególnie należąca do Elliotta

[13] F. Wasser, Steven Spielberg's America, Cambridge, Malden 2010, s. 104.

[14] Zob. H. Böhme, Fetyszyzm i kultura. Inna teoria nowoczesności, przeł. M. Falkowski, Warszawa 2012, s. $117,206$.

[15] Zob. W. Benjamin, Paryż - stolica dziewiętnastego wieku, [w:] idem, Anioł historii, przeł. H. Orłowski, Poznań 1996, s. 327.

[16] Motyw telekinetycznych przekształceń dziecięcej przestrzeni prawdopodobnie został podpatrzony przez Spielberga w ekranizacji Ucieczki na górę czarownic (1975, reż. J. Hough), w której kilkuletnie bliźnięta z kosmosu bawią się w swojej sypialni, unosząc zabawki i przybory plastyczne, a w finale, uciekając przed złoczyńcami chcącymi wykorzystać ich siły, wzbijają się w niebo furgonetką. O ile jednak disnejowska produkcja przedstawia fantastyczne sztuczki przybyszy w raczej realistycznej i beznamiętnej tonacji, o tyle Spielberg ukazuje niezwykłe sytuacje w poetyce cudowności. Zaaranżowane w podobny sposób sceny $\mathrm{z}$ wirującymi w powietrzu kulami będą powracać w filmach jego naśladowców. W Ostatnim gwiezdnym wojowniku (1984, reż. N. Castle) nastolatek będzie ze zadziwieniem przyglądał się poruszanemu wiatrem modelowi układu planetarnego, a w pierwszej sekwencji horroru Cameron (1988, reż. A. Mastroianni), opowiadającym o chłopcu i potworze z szafy, mały bohater przeniesie w powietrzu kolorowe piłki za pomocą siły umysłu.

[17] Zob. A.D. Lowell, op.cit., s. 51.

[18] Ibidem. 
sypialnia z garderobą kreowana jest na wygodny i intymny zakątek. Pomarańczowo-brązowa kolorystyka pokoju, który stale przepasany jest cieniami, przypomina konwencję, w jakiej czasem prezentuje się $\mathrm{w}$ filmach tajemnicze księgarnie, biblioteki i sklepy $\mathrm{z}$ antykami. W kontekście dziecięcego patrzenia na świat poetyka E.T. pełni istotną funkcję. Filmowa strategia, w której starannie kształtuje się nastrojowość dziecięcej przestrzeni, współgra z perspektywą, z jakiej wnętrza postrzegane są przez ludzi przed okresem dojrzewania. Znawca dziecięcej przestrzeni Christopher Day twierdzi, że niedorośli odczuwają wrażenia płynące z przebywania w przestrzeni głównie poprzez ich nastrój. O ile dla dorosłych konkretne pomieszczenie łączy się przeważnie $\mathrm{z}$ jedną nastrojowością, o tyle w przypadku dzieci jeden pokój może być wypełniony całą gamą różnych doznań. Wynika to z mniejszego rozmiaru patrzącego, a co za tym idzie, $\mathrm{z}$ większej skali przedmiotów, a także bardziej emocjonalnego niż praktycznego stosunku młodszych ludzi do otoczenia[19]. Dzieci wiedzą, w jaki sposób każdy fragment podłogi wygląda przy konkretnej pogodzie i są bardziej niż dorośli zaznajomione z przeobrażeniami swojej przestrzeni mieszkalnej w zależności od pory dnia[20]. Taki sposób odnajdywania się w otoczeniu odznacza się czułością na obecne w nim niuanse związane ze światłem i kolorem. W filmie Spielberga kluczem do wskrzeszenia domowej magii było właśnie światło.

Podczas seansów E.T. połączonych z czytaniem wspomnień jego twórców coraz wyraźniej jawi się fakt, że w tym filmie sposób, w jaki świat „widzi” kamera, pokrywa się ze sposobem patrzenia dziecka. Roger Ebert w jednym ze swych listów pisał, że „w żadnym istotnym dla filmu momencie kamera nie przejmuje roli dorosłego. Cały czas patrzymy na świat oczyma dziecka albo obcego"[21]. Na ile ten efekt był dziełem uświadomionej strategii, a na ile wynikiem przypadku, powinni orzec biografowie. W specjalistycznych wywiadach reżyser i operator Allen Daviau podkreślali, że chodziło o „realizm” i pietystyczne podejście do kwestii warsztatowych. Spielberg, opisując współpracę $\mathrm{z}$ autorem zdjęć, podkreśla dbałość o metamorfozy sypialni Elliotta w zależności od położenia słońca:

\begin{abstract}
Na bardzo wczesnym etapie naszej współpracy rozmawialiśmy o pomysłach na styl oświetleniowy. Chciałem, żeby film wyglądał bardzo realistycznie, co znaczy, że jeśli jest 10 rano, to światło w sypialni Elliotta wpada prosto przez obydwa okna i rolety, które będą bardzo gorące, w przeciwieństwie do pozostałej części pokoju okrytej mrokiem [...]. Allen był bardzo, bardzo czujny, jeśli chodzi o porę dnia, a nawet o to, jak się ona zmienia. Widać to po wyglądzie pokoju Elliotta, kiedy chłopiec symuluje chorobę z termometrem w ustach, a matka kładzie go do łóżka, to znaczy jeszcze zanim zaczynają się lekcje, koło 8:30 rano, gdy słońce bardzo mocno przedziera się przez wszystkie warstwy i razi w oczy. W czasie, kiedy skończyły się lekcje
\end{abstract}

[19] Zob. C. Day, Environment and Children: Passive lessons from the everyday environment, Boston 2005, s. 5 .
[20] Zob. ibidem, s. 8.

[21] R. Ebert, The Great Movies, New York 2002, s. 254. 
i Michael, brat Elliotta, wrócił do domu, by po raz pierwszy spotkać E.T., całe źródło światła przesunęło się i nie płynęło już z okien nad łóżkiem Elliotta, ale z okien przy biurku, przemieszczając się przez całe niebo. Allen bardzo pilnował położenia słońca[22].

Dzięki uchwyceniu położenia słońca w konkretnych porach dnia udało się odtworzyć zmysłową atmosferę wnętrz, które - przykładowo dla dziecka unikającego dnia w szkole mogły wydać się przestrzenią niemal odświętną. Istotne jest, że w pokoju Elliotta nigdy nie jest w pełni jasno ani całkowicie ciemno. W ciągu dnia smugi światła wpadają do środka przez nagie okiennice i tęczowe żaluzje, jednak nawet wtedy duża część pomieszczenia zanurzona jest w półmroku. Sceny nocne i wieczorne ukazują natomiast sypialnię częściowo oświetloną ciepłymi promieniami płynącymi z porozstawianych gdzieniegdzie lampek biurowych (czasem przykrytych pomarańczową chustką). W jeden z wiszących kloszy E.T. zaplącze się w wyniku zdenerwowania towarzyszącego pierwszemu spotkaniu. Ruszająca się lampa rzuci migające cienie na twarze chłopca i kosmity. Oświetlenie w pokoju raz płata figle, a raz jest miarowe. Przedzierające się przez ciemność światło żarówek tworzy kameralną aurę. Day twierdzi, że właśnie taka nastrojowość jest idealnym tłem dla dzieci, które mają ochotę zaszyć się w kocu, snuć marzenia i przebywać w świecie „pomiędzy”: „Z trollami, fantastycznymi krainami i marzeniami dziennymi jest tak, że w pełnym świetle dnia zamieniają się w kamień. Potrzebny jest im magiczny nastrój rodzaj zmierzchu, ale nie aż tak mroczny" [23]. W E.T. lampy, lampiony i świeczki ogrzewają dom po zmroku. Ekipa filmowa wspominała, że dekoratorki wnętrz przyniosły na plan tuziny stojących i biurowych lamp. Chodziło o stworzenie fantastycznych barw, sprawiających jednak wrażenie, że kolory pochodzą z naturalnego źródła[24]. W pokoju Elliotta standardowe oświetlenie sufitowe zostało pokazane tylko w jednej scenie, która ostatecznie nie została wykorzystana w filmie. Autor zdjęć z żalem wspomina fragment mieniący się blaskiem domowych iluminacji:

Dochodzi pierwsza, kiedy matka Elliotta wzywa go na górę. Jedyny raz w całym filmie widzimy górne światło. W trakcie wysłuchiwania pouczeń Elliott gasi górne światło tak, że jego matka zostaje zredukowana do obrysu postaci, a później chłopiec zapala wszystkie malutkie światełka, które umieścił w pokoju, dostrajając oświetlenie do swoich wymagań. Wycięli tę scenę, cholera, ale była cudowna, bo ustanowiła punkt, z jakiego będą pochodzić wszystkie światła użyte w scenach rozgrywających się w tym pokoju[25].

Nie tylko pokój Elliotta rozjaśniany jest lampkami. Charakterystyczne przebitki ukazujące małe światełka otwierają i zamykają niektóre sceny przedstawiające życie w pozostałej części domu. Jedno $\mathrm{z}$ takich ujęć koresponduje $\mathrm{z}$ fragmentem przywoływanym przez Da-

[22] G.E. Turner, op.cit., s. 8o-82.

[23] C. Day, op.cit., s. 24.
[24] Zob. L. Kent, The cinematography of E.T., „American Cinematographer" 1983, vol. 64, no. 1, s. 88. [25] Ibidem. 
viau. Tym razem to matka chłopca zmienia świetlną oprawę domu. Kiedy w halloweenową noc Mary zamartwia się, że dzieci nie wróciły jeszcze do domu, zdmuchuje płomienie dekoracyjnych świeczek. Zdenerwowana kobieta próbuje zgasić niziutkie, stopione już świeczki poprzez uderzanie w nie różdżką będącą częścią jej przebrania. Różdżka nie działa jednak od razu i płomień gaśnie dopiero, gdy zirytowana bohaterka uderza w niego piąty raz. Inne ujęcie, ukazujące jack-o'-lantern, będzie natomiast zapowiedzią przejęcia domu przez rządowych funkcjonariuszy. Najpierw w korytarzu, a później w pokoju Gertie ujrzymy przesuwające się cienie, znajome każdemu dziecku, które z niepokojem obserwuje ruch odbić świetlnych migających na ścianie swego pokoju.

Sekwencja halloweenowa zajmuje mniej niż kwadrans filmu, ale nastrojowość tego święta przyświeca całemu dziełu. Lisa Morton w książce Trick or Treat. A history of Halloween pisze, że Halloween ujęte w "ciepłym blasku nostalgii” ustanawia w filmie tonację magii i cudowności[26]. Podobne spostrzeżenia znajdziemy w recenzji Pauline Kael, często przywoływanej przez analityków E.T. Krytyczka zauważa, że rodzaj wyobraźni wizualnej znamionującej cały film zaczerpnięty jest z ikonografii Halloween i w takim otoczeniu nawet statek kosmiczny wygląda jak „dyniowy lampion zawieszony na niebie” [27]. Czy w tym sensie elementem świetlnej estetyki październikowego święta nie byłoby także migocące ciało tytułowego bohatera? Jesienne imaginarium E.T. było na tyle sugestywne, że w latach osiemdziesiątych zainspirowało estetykę amerykańskiego kina grozy. John Kenneth Muir w kontekście horroru Biała dama (1988, reż. F. LaLoggia), dotkniętego, jak mówi, „syndromem Piotrusia Pana”, opisuje specyficzną tonację tej pseudospielbergowskiej produkcji: trwa Halloween, w powietrzu unosi się jesienna atmosfera, kadry wypełnia pomarańczowe światło[28]. Polemizując z opinią Jerzego Szyłaka, który w Kinie Nowej Przygody z niesmakiem charakteryzuje symbolikę wizualną filmu jako „wulgarną trawestację ikonografii chrześcijańskiej"[29], stwierdzimy, że dzieło Spielberga w równym stopniu odwoływać może się do wyobrażeń chrześcijańskich, jak i obrazów zakorzenionych w baśniach i estetyce współczesnego Halloween. W perspektywie wizualnej kultury dziecięcej jarzący się palec pozaziemskiej istoty imituje magiczną różdżkę[30], a rozniecone pomarańczowym blaskiem serce przypominać może jeszcze jeden lampion.

Kolejnym niekonwencjonalnym źródłem światła jest okrągły witraż w szafie, służącej przybyszowi za kryjówkę. Kolorowe okienko

Brzuch domu albo szafa marzeń
[26] Zob. L. Morton, Trick or Treat. A history of Halloween, London 2012, s. 97, 188.

[27] P. Kael, Taking it All in, New York 1984, s. 348.

[28] Zob. J.K. Muir, Horror Films of the 1980s, Jefferson, London 2007, s. 671.
[29] J. Szyłak, E.T. (E.T.: The Extra Terrestrial), w: J. Szyłak i in., Kino Nowej Przygody, Gdańsk 2001, s. 169.

[30] Zob. P. Krämer,'I'll be right here!' Dealing with emotional trauma in and through E.T. The extra-terrestrial, [w:] Children in the Films of Steven Spielberg, red. A. Schober, D. Olson, Lanham 2016, s 103. 
zostało zamontowane, aby można było rozróżnić pory dnia i uzasadnić pochodzenie rozproszonego pomarańczowego światła, w jakim skąpane jest wnętrze garderoby. Widoczna w kadrze lampa z położoną na kloszu żółtą chustką stworzyła efekt określony przez Spielberga „figlarnym zachodem słońca”[31]. Szafa kryje niezwykłą przestrzeń, ale z zewnątrz prezentuje się jak każda inna żaluzjowa garderoba, popularna w sypialniach przedmiejskich domów. Konstrukcja zaprojektowana jest tak, że podwójne drzwi otwierają się z obydwu stron na sypialnie Elliotta i Gertie. Garderoba jest zatem chroniona przez okalające ją pokoje dzieci i nie ma styczności z żadnym z pomieszczeń należących do matki. Wprawdzie pokój Michaela mieści się w innej części budynku, wiemy jednak, że dziecięca kryjówka w szafie należy również do najstarszego z trójki rodzeństwa bohatera. Podczas przejęcia domu rodzinnego przez naukowców (których przybycie zostało zwizualizowane przez transformację domu z małego, uroczego gniazdka w zimny aseptyczny szpital) garderoba zdaje się ostatnią bezpieczną przestrzenią. W jej miękkim, ciepłym wnętrzu zasmucony nastolatek kuli się w kłębek i zasypia - bardziej jak kilkuletni chłopiec niż prawie dorosły mężczyzna. Szafa jest przestrzenią dzieci.

Urządzenie tych przytulnych wnętrz było dla twórców wyzwaniem. Spielberg stwierdził, że potrzebna była improwizacja, gdyż „dotychczas niewiele filmów rozgrywało się w dziecięcej szafie”[32]. W twórczości reżysera szafa, jako istotny punkt domu, będzie powracać w opowieściach dotyczących rodzinnego życia małych bohaterów. Pierwszy raz pojawi się w Duchu (1982), gdzie szafa w pokoju dziecięcym pełni odwrotną niż w E.T. funkcję - jest demoniczną czeluścią wciągającą do swego potwornego wnętrza wystraszoną dziewczynkę. Natomiast w późniejszym A.I. Sztuczna inteligencja (2001) garderobiana szafa posłuży zniecierpliwionej matce do zamknięcia wewnątrz wchodzącego jej pod nogi chłopca-androida. Kiedy w końcu otworzy mu drzwi, David zapyta ufnie: „Czy to gra?”. Najbliższy E.T. sposób ukazywania domowej przestrzeni z perspektywy dziecka zaproponuje scenarzystka Melissa Mathison w filmie Indianin w kredensie (1995, reż. F. Oz), w którym dziecięca tematyka, styl oświetleniowy i motyw czarodziejskiej skrytki będą świadczyć o próbie wskrzeszenia dawnej magii produkcji Spielberga.

Choć, jak sugerował sam reżyser, przed latami osiemdziesiątymi szafa nie pełniła w kinie amerykańskim roli symbolu czy istotnej scenerii, to twórcy E.T. mieli do dyspozycji blisko dwusetletnią tradycję literatury dziecięcej i fantastycznej, w której ten element domowej przestrzeni był popularnym motywem. Kanonicznym tekstem jest Lew, czarownica i stara szafa C.S. Lewisa, ale jak wykazuje Maria Nikolajeva, magiczne szafy i garderoby pojawiały się także w powieściach i opowiadaniach Edith Nesbit, George'a MacDonalda, E.T.A. Hoffmanna i innych autorów eksplorujących temat fantastycznego dzieciństwa[33].

[31] G.E. Turner, op.cit., s. 8o. [32] Ibidem, s. 82.
[33] Zob. M. Nikolajeva, Children's Literature Comes of Age: Toward a new aesthetic, London, New York 1996, s. $183-184$. 
E.T. tym jednak różni się od literatury, w której zwyczajowo traktowano szafę jako portal (drzwi do magicznych światów, wehikuł czasu lub czarodziejskie pudło), że w filmie akcentuje się raczej „realistyczno-magiczne" istnienie szafy niż jej efektowne paranormalne funkcje. Szafa nie prowadzi do innych krain, lecz sama staje się małą, zaklętą krainą. Dla dorosłych jest to zwyczajne miejsce. Mary otwiera i zamyka garderobę ślepa na cuda, jakie odbywają się w jej wnętrzu. Taka bezmyślność jest typowa dla dorosłych, którzy, wiedzeni szałem sprzątania, potrafią na przykład zetrzeć magiczne ślady w szafie - pisze Nikolajeva[34]. W jednej z najsłynniejszych scen filmu widzimy, jak zabiegana matka studiuje wzrokiem wnętrze garderoby, ale nie dostrzega pyszczka E.T. wkomponowanego w chmarę kolorowych maskotek.

W oczach dorosłych szafy i garderoby spełniają funkcje praktyczne. Jednak nawet ich powszednie użytkowanie jest w pewnym sensie związane z domowymi sekretami. Jadwiga Mizińska, omawiając niezwykły charakter codziennych przestrzeni domu, zauważa, że szafa przywodzi na myśl tajemnicę[35]. Trzyma się tam przedmioty, które albo są zbyt intymne czy nieatrakcyjne i nie wypada prezentować ich na zewnątrz, albo są na tyle odświętne, że nie chcemy, aby banalizowały się, niszczyły i kurzyły w świetle dnia. Dobra szafa powinna być głęboka i pojemna niczym „brzuch domu”, zdolny skryć w swym wnętrzu nie tylko pierzyny, płaszcze i kosztowności, ale też „potrzebujących Jonaszy”[36]. Choć metaforyka filozofki odnosi się w dużym stopniu do mebli, w których podczas II wojny światowej ukrywano Żydów, to opiekuńczy i sekretny charakter tych punktów na mapie domu jest wyobrażeniem kulturowym o szerszym charakterze. Jedną z jego inkarnacji jest film Spielberga.

W E.T. garderobiana szafa została stworzona na wzór zaczarowanej skrytki. Spielberg tłumaczył, że ujęcia w jej wnętrzu musiały różnić się od fragmentów kręconych w pokoju Elliotta - magia E.T. powinna przecież szczególnie intensywnie roztaczać się w tymczasowej siedzibie kosmity. Ten zakątek jest zatem, przywołując słowa twórcy, „cudowną krainą” i „magiczną kryjówką" [37]. W myśli Gastona Bachelarda taki "pokój w głębi” jest obrazem przywoływanym, gdy snuje się marzenia o domu. Francuski filozof, pisząc o domu onirycznym, analizuje obrazy, jakie łączą się z marzeniami dziennymi krążącymi wokół schronienia i bezpiecznej samotności - dziecięcych wspomnień tych momentów, gdy zaszywaliśmy się w ciemnych, ciasnych zakamarkach, by w samotności marzyć[38]. Z takim ukojeniem łączą się widok chatki z zapalonymi światłami, wnętrze dziupli i właśnie „najskrytsze izdebki” domu. Dziecięca samotność wewnątrz domu pozwala snuć twórcze fantazje. Gdy zatem Elliott na początku filmu zatrzaskuje drzwi sypialni, zagłę-

[34] Ibidem, s. 184.

[35] Zob. J. Mizińska, Duchy domu, Lublin 2006, s. 50.

[36] Ibidem, s. 50-52.

[37] G.E. Turner, op.cit., s. 8o.
[38] Zob. G. Bachelard, Ziemia, spoczynek i marzenia, przeł. A. Tatarkiewicz, [w:] idem, Wyobraźnia poetycka. Wybór pism, przeł. H. Chudak, A. Tatarkiewicz, Warszawa 1975, s. 301-330. 
bia się w sferę wyobraźni i odnajduje w przybyszu siebie samego. Co prawda E.T. odgrywa w filmie rolę pełnoprawnego bohatera, nie jest jednak przypadkiem, że chłopiec i kosmita dzielą emocje, doznania fizyczne, gesty, a nawet imiona (skrót od Extra Terrestrial pokrywa się z pierwszą i ostatnią literą imienia chłopca). Elliott i najbliższa mu istota żyją również we wspólnej przestrzeni mieszkalnej, której najgłębszym i najintymniejszym punktem jest szafa. Z psychoanalizy marzeń Bachelarda dowiemy się, że „dziecko, zamykając się, pragnie żyć wyobraźnią; mogłoby się zdawać, że sny są tym śmielsze im azyl ciaśniejszy”[39]. Zbliżone obserwacje znajdziemy u antropologów, pedagogów, eseistów.

Wizja przestrzenna uprzywilejowująca miejsca niewielkie, zacienione i nie zawsze pierwotnie zaplanowane jako małe pokoiki, jest zbieżna z upodobaniami architektonicznymi dzieci. W jakich wnętrzach niedorośli czują się naprawdę dobrze? Badacze przestrzeni dziecięcej określali takie przestrzenie różnorakimi terminami. Christopher Day pisał o „gniazdo-zakątkach”[40], David Sobel w kontekście tworzenia baz analizował „wyjątkowe miejsca dzieci”[41], Matthew Burgess wybrał poetyckie określenie „szafa marzeń”[42]. Pomimo odmiennych podejść metodologicznych i warsztatowych wyraźnie rysują się wspólne dla nich konstatacje. W ostatnich dziesięcioleciach na polach różnych dyscyplin oscylujących wokół odbioru środowiska lokalnego (domu, szkoły, podwórka) przez dziecko zauważalne było zainteresowanie tymi miejscami, które chłopcy i dziewczynki uznawali za wyjątkowe, ulubione, przesycone najprzyjemniejszą atmosferą. Praca na biografiach i metody statystyczne ujawniły, że w przypadku dzieci mniej więcej w wieku dziesięcioletniego bohatera filmu ważną rolę odgrywają różnego rodzaju dziuple, kąciki, zakamarki i głębokie meble. Olivier Marc twierdzi, że „jeśli dać dziecku karton o odpowiednich wymiarach, to z pewnością będzie próbowało wdrapać się do środka"[43]. Czy podobne pragnienie można przypisać tytułowemu bohaterowi, gdy kryje się w przydomowym schowku na narzędzia?

Znamienne, że jedyna - przedwczesna - próba opuszczenia bezpiecznej szafy kończy się dla kosmity agonią. Powrót do życia realizuje się natomiast dopiero w momencie, gdy ciało E.T. zostaje złożone w pudle zamrażarki. Tego rodzaju filmowe metafory czytane są przez analityków filmu jako obrazy „powrotu do łona”, którego ostatecznym sfinalizowaniem jest zagłębienie się bohatera we wnętrzach „statku matki" [44]. Symbole, czytane zgodnie z klasyczną freudowską wykładnią, świadczyłyby o regresywnej wizji dzieciństwa, jaka uwidacznia się w filmie Spielberga. W kontekście sekretnych miejsc badacze przestrzeni dziecięcej chętniej zwracali jednak uwagę na fakt, że kryjówki są

[39] Ibidem, s. 314 .

[40] C. Day, op.cit., s. 124-126.

[41] D. Sobel, Children's Special Places: Exploring the role of forts, dens, and bush houses in middle childhood, Detroit 1993.
[42] Zob. M. Burgess (red.), Dream Closet. Meditations on childhood space, New York 2016.

[43] O. Marc, Birth of the house, [w:] The Domestic Space Reader, red. K. Mezei, C. Briganti, Toronto, Buffalo, London 2012, s. 259.

[44] P. Krämer, op.cit., s. 112. 
nie tylko „strefami komfortu”, ale też przestrzeniami eksperymentów i eksploracji[45]. Przebywanie w tego rodzaju miejscach wiąże się z odnajdywaniem własnego kawałka ziemi, prywatnego domu, należącego tylko do dziecka, co pozwala bardzo młodym ludziom odpocząć i snuć marzenia. To tryb bliski regeneracji określanej przez introwertyków jako „ładowanie baterii życiowych”, tyle że przebiega ona w atmosferze tajemnicy, magii, a nawet przygody. Dawna rezydentka ulokowanego w piwnicy kącika nazywanego przez nią czule The Hole opisuje znajomą dzieciom nastrojowość: „Czułam, że to miejsce tak bezpieczne jak schron bombowy i ekscytujące niczym inna planeta" [46]. Podobne spostrzeżenia na temat dziecięcych „szaf marzeń” snuje Matthew Burgess. Jego dawne skrytki nie tylko oddzielały go od intruzów, ale posiadały też magiczne moce - w każdej chwili mogły stać się latającym dywanem, rakietą kosmiczną albo lampą dżina[47].

Pociąg niedorosłych do odkrywania na własny użytek miejsc dostosowanych do swego rozmiaru może wyrażać się poprzez budowanie - tworzenie na wolnym powietrzu szałasów, fortów i baz - albo przejmowanie przestrzeni już istniejących: kufrów i kredensów, wolnego miejsca pod biurkiem, nieatrakcyjnych dla dorosłych dziwnych otworów w piwnicy i na strychu. Szafa często wymieniana jest pośród „wyjątkowych miejsc dzieci”. We wspomnieniach skrytek wewnątrz domu, jakie analizuje architektka Clare Cooper Marcus, pojawia się wypowiedź dawnej lokatorki przytulnej skrytki. Kobieta wspomina, że w dzieciństwie jej ulubioną kryjówką była garderoba: „Miała drzwi, które dało się otwierać zarówno z zewnątrz, jak i od środka, a wewnątrz było światło. Była na tyle duża, że mieściło się w niej troje ludzi, ale często wolałam zatrzasnąć drzwi i zamknąć się w środku, żeby pobawić się «W dom» albo poczytać książki”[48]. W artykule Kimberly Dovey jednym z miejsc „odpoczynku i fantazji” była szafa, którą jej niegdysiejsza właścicielka pamięta jako absolutnie bezpieczną przestrzeń:

Spędzałam w szafie samotnie wiele godzin - tam czytałam, marzyłam, płakałam [...]. W środku było tak spokojnie, że mogłam skupić się na tym, czego ja sama pragnęłam, a nie czego wymagali ode mnie inni. Oddawałam się marzeniom i snułam plany na przyszłość[49].

Szafa w filmie Spielberga zachęca do podejmowania podobnych „introwertycznych” aktywności. Czynnością, której E.T. z największym zaangażowaniem oddaje się w swoim "domu wewnątrz domu”, jest czytanie komiksów. We wnętrzu szafy można też schować swój smutek, tak jak robił to Michael, albo bawić się w „przebieranki” na wzór Gertie, która przyozdobiła przybysza dziewczęcymi ubraniami.

[45] Zob. D. Sobel, op.cit., s. 72-73.

[46] Idem, A place in the world: Adults' memories of childhood's special places, „Children's Environments Quarterly” 1990, vol. 7, no. 4, s. 9.

[47] Zob. M. Burgess, op.cit., s. 12.
[48] C. Cooper Marcus, Environmental memories, [w:] Place Attachment, red. I. Altman, S.M. Low, New York, London 1992, s. 91.

[49] K. Dover, Refuge and imagination: Places of peace in childhood, „Children's Environments Quarterly” 1990, vol. 7, no. 4, s. 15. 
Opiekuńczy charakter tego miejsca sugestywnie wyraża czuła scena, w której E.T. leczy zraniony palec chłopca, a Elliott okrywa przybysza kocem i szalikiem. Z sąsiedniego pokoju słychać fragment Piotrusia Pana - innej historii o magicznej postaci, która pojawia się niespodziewanie w dziecięcej sypialni. Elliott i E.T., spleceni w uścisku, prawie jak jedna istota, słuchają bajki, którą mama Gertie czyta dziewczynce na dobranoc. Siedząc w ciemności, obserwują przez uchylone żaluzje garderoby pokój dziewczynki. Ta niemal kinowa sytuacja[50] będzie jedną z ostatnich spokojnych chwil przyjaciół. Niedługo później pokoje dziecięce zostaną przejęte przez pozbawionych twarzy naukowców. Neil Sinyard w Children in the Movies pisze, że w momencie „gdy ludzie z NASA zjawiają się w filmie, by przebadać E.T. jako naukowy fenomen, dziecięcy sposób patrzenia jest już tak bardzo nasz, że naukowcy wydają się nam bardziej obcy niż obcy"[51].

Wyjście z szafy

Prace badaczy zainteresowanych sekretnymi dziecięcymi miejscami ujawniają, że w pewnym wieku tajemnicze szafy i przytulne bazy są porzucane na rzecz bardziej przestronnych przestrzeni[52]. Dwunasto- czy czternastolatki coraz chętniej skłaniają się ku miejscom pełnym witalizmu i żywiołowej rówieśniczej energii aniżeli intymnym, magicznym zakątkom. Starsze dzieci preferują też inny rodzaj oświetlenia - jasne światło sprzyjające raczej czujności i myśleniu, a nie półmrok odpowiedni do zagłębiania się w marzenia[53]. Ciasne, ciemne kąty zamieniane są na bardziej otwarte przestrzenie, które odpowiadają rozmiarowi patrzącego - już nie postaci o wymiarach E.T. i Elliotta, lecz osoby o wzroście naukowców i matki chłopca.

Dorośli widzą przestrzeń inaczej niż dzieci, co tyczy się również kina. Niektórzy twórcy decydują się jednak na strategię „dziecięcego spojrzenia”. Założenie, że filmowiec (a także antropolog, pedagog, poeta) dysponuje pełnym dostępem do doświadczeń i wrażliwości dziecka, jest z całą pewnością błędne, jednakże głęboka artystyczna intuicja i osobista pamięć mogą pomóc w obraniu „spojrzenia dziecka”. Alicja Helman w artykule Spojrzenie dziecka metafora kina dostrzega je zarówno w kinowym dyspozytywie, jak i w szczególnej konstrukcji narracji z punktu widzenia dziecka (dominuje w niej układanie własnego świata ze strzępków niezrozumiałego świata dorosłych)[54]. Wśród wymienionych przez badaczkę filmów pojawiają się Pokuta (2007, reż. J. Wright), Niebieski latawiec (1993, reż. Zhuangzhuang Tian) oraz dzieła Carlosa Saury i Víctora Erice - często przywoływane również przez innych analityków zainteresowanych filmami o dzieciństwie[55]. Na

[50] Zob. N. Morris, The Cinema of Steven Spielberg: Empire of light, London, New York 2007, s. 90. [51] N. Sinyard, Children in the Movies, Batsford, London 1992, s. 34 . [52] Zob. C. Day, op.cit., s. 30; D. Sobel, Children's Special Places..., s. 35.

[53] Zob. C. Day, op.cit., s. 102.
[54] Zob. A. Helman, Spojrzenie dziecka metafora kina, „Kwartalnik Filmowy” 2013, nr 81, s. 24-38. [55] Zob. S. Thomas, Inhabiting the In-Between: Childhood and cinema in Spain's long transition, Toronto, Buffalo, London 2019, s. 120; V. Lebeau, Childhood and the Cinema, London 2008, s. 50-55. 
słynnego Ducha roju (1973) powołuje się również Mark Cousins w eseju dokumentalnym Opowieść o dzieciach i filmie (2013). Mówiąc o istotnej dla przedstawiania dziecięcego świata roli kadrowania, poświęca on uwagę realizacjom, w których subiektywna kamera obiera punkt widzenia dziecka, czego przykłady stanowią Gasman (1997) Lynne Ramsay oraz Ja, Julinka i koniec wojny (1965) Karela Kachyňy. W tych filmach dorośli ukazywani są fragmentarycznie - w brytyjskim „krótkim metrażu" nie widać ich twarzy, a w czechosłowackiej realizacji matka małego bohatera przytłoczona jest szerokim sufitem, który jej syn ogląda, zasypiając w łóżku. Podobne rozwiązania stosuje Spielberg, gdy decyduje się pozbawić twarzy prawie wszystkich dorosłych bohaterów i filmuje sufity, „jak gdyby Elliott spoglądał na swojego starszego brata" [56]. W E.T. pojawiają się też ujęcia z punktu widzenia dziecka lub kosmity, w których, tak jak podczas sceny halloweenowej albo słuchania opowieści o Piotrusiu Panie, przestrzeń jest częściowo zakryta (przez kostium ducha lub listwy rolety). Filmowe „spojrzenie dziecięce” nie musi być jednak definiowane przez jego deficyty (formułowane w stosunku do „spojrzenia dorosłych”), lecz może służyć za pełnoprawną, autonomiczną strategię przedstawienia, co dobrze widać w większości scen rozgrywających się w pokoju i szafie Elliotta.

A jednak historia kina pokazuje, że bardzo często to wedle „spojrzenia dorosłego" buduje się filmowy świat przedstawiony. W kontekście niniejszej analizy właścicielem „spojrzenia dorosłego” byłby ktoś, kto, mówiąc metaforycznie, wyszedł z szafy, zapalił górne światło i poukładał zabawki. Ktoś, kto operuje niemagicznym sposobem widzenia. Hartmut Böhme pisze, że ten, kto pragnie być dorosły, musi podzielić świat na żywe i martwe przedmioty i przeciwstawić je sobie jako konstytuującemu podmiotowi[57]. Dla dorosłych świat przedmiotów jest poukładany: szafa nie jest mieszkaniem, lecz służy do przechowywania ubrań, parasolka to nie żaden kosmiczny telefon, a ochrona przed deszczem, jedzenie nie służy do zabawy, rower nie ma prawa lewitować. W kinie owo „spojrzenie dorosłego” przekłada się na „przezroczystą” poetykę. Nierzadko nawet $\mathrm{w}$ filmach opowiadających o dzieciństwie to właśnie preferencje dorosłych wyznaczają kąty ustawienia kamery, styl oświetleniowy, lokalizacje, pomysły scenograficzne, sposób traktowania rekwizytów. „Spojrzenie dorosłego” (wyznaczone w kontrze do omówionej w tekście propozycji czytania wnętrz w filmie Spielberga) byłoby zatem nieczułe na „nastrój” przestrzeni - obojętne na detale związane ze światłem i fakturą miejsca.

Im przestrzeń jest bardziej konwencjonalna i użytkowana zgodnie ze swoim pierwotnym przeznaczeniem, tym mniej jest atrakcyjna w oczach dziecka. Schowki, zagłębienia pod schodami albo wielkie szafy są oczywiście tylko kilkoma punktami, jakie mogą pojawić się na filmowej mapie studiowanej „spojrzeniem dziecka”. Takich niezwykłych miejsc jest nieskończenie wiele, gdyż ich odnalezienie zależy raczej od 
sposobu patrzenia na przestrzeń niż od lokalizacji jako takiej. Filmowy sposób patrzenia niedorosłego jest zatem strategią dostrzegania niezwykłości w tym, co codzienne. To wizja ujawniająca intrygujące zakątki, nastrojowe światło, fantazyjne cienie, ekscytujące przedmioty.

Stwierdzenie, że w E.T. ukazana jest dziecięca wizja świata, może wydać się banałem. O ile jednak film Spielberga czytany jest przez analityków jako konserwatywny (bo afirmujący przedmieścia i życie rodzinne, czym ma wpisywać się w ducha reaganizmu), o tyle jego lektura czuła na nastrój i urodę kadrów przedstawia dzieło w nieco innym świetle. Jeśli wierzyć ustaleniom badaczy intymnej przestrzeni dzieci, „szafa marzeń” w E.T. odpowiada wrażliwości typowo dziecięcej często spychanej na margines przez racjonalizujące, obiektywizujące oko dorosłego. Taka intymna kryjówka jest miejscem egalitarnym i zabezpieczającym autonomię dziecka. To przestrzeń znana kilkulatkom niezależnie od ich płci, kultury i pochodzenia społecznego. David Sobel twierdzi nawet, że jest ona odpowiedzią na niemalże uniwersalną dla wszystkich dzieci potrzebę znalezienia swojego własnego, intymnego miejsca[58]. Z biografii byłych lokatorów takich zakątków wynika jednocześnie, że te wnętrza są gościnne zarówno dla szczęśliwych, jak i nieszczęśliwych dzieci. Mając zatem na uwadze, że E.T. przedstawia, rzecz jasna, otoczenie chłopca mieszkającego na amerykańskich przedmieściach doby Ronalda Reagana, możemy stwierdzić, że dzieło Spielberga, wbrew pozorom, naznaczone jest stosunkowo wspólnotową orientacją. Linia podziału kreślona jest w nim między dziecięcością a dorosłością, przy czym wykluczeniu poddana jest dorosłość mierzona nie metryką, ale dobrą pamięcią autobiograficzną. Patrząc na E.T. przez pryzmat „spojrzenia dziecka”, dostrzeżemy głęboko osobisty, ale i uniwersalny wymiar, w jakim usytuowana jest magiczna szafa - miejsce marzeń i odpoczynku.

Bachelard G., Wyobraźni poetycka. Wybór pism, G. Bachelard, przeł. H. Chudak, A. Tatarkiewicz, Warszawa 1975

Bartlett S., Chawla L., Introduction, „Children’s Environments Quarterly” 1990, vol. 7, nr 4

Benjamin W., Anioł historii, przeł. H. Orłowski, Poznań 1996

Böhme H., Fetyszyzm i kultura. Inna teoria nowoczesności, przeł. M. Falkowski, Warszawa 2012

Burgess M., Dream Closet. Meditations on Childhood Space, New York 2016

Cooper Marcus C., Environmental memories, [w:] Place Attachment, red. I. Altman, S.M. Low, New York, London 1992

Day C., Environment and Children: Passive lessons from the everyday environment, Amsterdam 2005

Dover K., Refuge and imagination: Places of peace in childhood, „Children's Environments Quarterly" 1990, vol. 7, no. 4

Ebert R., The Great Movies, New York 2002

[58] Zob. D. Sobel, Children's Special Places..., s. 6-7. 
Hannigan F., Filmcraft: Production Design, London 2013

Helman A., Spojrzenie dziecka metafora kina, „Kwartalnik Filmowy” 2013, 81

Hoberman J., Make My Day: Movie Culture in the Age of Reagan, New York, London 2019

Kael P., Taking it All in, New York 1984

Kent L., The cinematography of E.T., „American Cinematographer” 1983, Jan.

Krämer P.,'I'll be right here!' Dealing with emotional trauma in and through E.T. The Extra-Terrestrial, [w:] Children in the Films of Steven Spielberg, red. A. Schober, D. Olson, Lanham 2016

Lowell A.D., Production design for E.T., „American Cinematographer” 1983, Jan, 64 Marc O., Birth of the house, [w:] The Domestic Space Reader, red. K. Mezei, C. Briganti, Toronto, Buffalo, London 2012

McFadzead A., Suburban Fantastic Cinema: Growing up in the late twentieth century, London, New York 2019

Mizińska J., Duchy domu, Lublin 2006

Morris N., The Cinema of Steven Spielberg: Empire of light, London, New York 2007

Morton L., Trick or Treat: A History of halloween, London 2012

Muir J.K., Horror Films of the 1980s, Jefferson, London 2007

Nikolajeva M., Children's Literature Comes of Age: Toward a new aesthetic, London, New York 1996

Reiter G., Fathers and Sons in Cinema, Jefferson, London 2008

Ruppersberg H., The Alien Messiah, [w:] Alien Zone: Cultural Theory and Contemporary Science Fiction Cinema, red. A. Kuhn, London, New York 1990

Sanello F., Spielberg: The man, the movies, the mythology, Lanham, New York, Oxford 2002

Sinyard N., Children in the Movies, London 1992

Sobel D., A place in the world: Adults' memories of childhood's special places, "Children's Environments Quarterly” 1990, vol. 7, no. 4

Sobel D., Children's Special Places: Exploring the role of forts, dens, and bush houses in middle childhood, Detroit 1993

Szyłak J., E.T. (E.T.: The Extra Terrestrial), [w:] J. Szyłak i in., Kino Nowej Przygody, Gdańsk 2001

Taylor P.M., Steven Spielberg: The man, his movies, and their meaning, London, Basford 1999

Thomas S., Inhabiting the In-Between: Childhood and cinema in Spain's long transition, Toronto, Buffalo, London 2019

Tibbetts J.C., Those Who Made It: Speaking with the legends of Hollywood, New York 2015

Turner G.E., Steven Spielberg and E.T. the extra-terrestrial, „American Cinematographer" 1983, Jan, 64

Wasser F., Steven Spielberg's America, Cambridge, Malden 2010

Wright J.W., Levinasian ethics of alterity: The face of the other in Spielberg's cinematic language, [w:] Steven Spielberg and Philosophy: We're gonna need a bigger book, red. D.A. Kowalski, Lexington 2008 